\title{
Menstrual Problems Among College Students: Prevalens and Treatment Seeking Behaviors
}

\author{
Hoirun Nisa 1, Alkausyari Aziz ${ }^{2}$, Erlina Nasution ${ }^{3}$ \\ Department of Public Health, Faculty of Health Sciences, Universitas Islam Negeri Syarif Hidayatullah \\ Jakarta', Polytechnic of Health, Pekanbaru, Riau2, Polytechnic of Health, Medan, North Sumatra ${ }^{3}$ \\ hoirun.nisa@uinjkt.ac.id
}

\section{Article Info}

\section{Article history}

Received date: 2019-12-02

Revised date: $2019-12-17$

Accepted date: $2019-12-26$

\begin{abstract}
Menstrual problems are highly prevalence, especially among young adults. However, the signs and symptoms of menstrual disorders are typically disregarded. This study aimed to evaluate the prevalence of menstrual problem and treatment seeking behavior. A cross-sectional study was conducted on 261 female college students. Data were collected using a structured questionnaire. Prevalence of premenstrual symptoms was $70.1 \%$, and that of dysmenorrhea was $93.6 \%$. Mothers were the main source $(65 \%)$ of information about reproductive heatlh. Mood-swings/irritability (88.1\%) and dysmenorrhea $(93.5 \%)$ were most common of premenstrual symptoms and menstrual syndrome, respectively. Half of participants experienced severe dysmenorrhea $(53.2 \%)$, however medical seeking behavior during menstrual period was poor $(18.8 \%)$. Participants did not seek treatment because their menstrual problems did not interfere with their daily activities (80.2\%). We conclude that health professionals should involve mothers in discussions about menstrual problems as mothers were the main source of information regarding reproductive health.
\end{abstract}

Keywords:

Menstrual problems, reproductive health, treatment seeking behaviors.

\begin{abstract}
Abstrak
Masalah terkait menstruasi merupakan masalah kesehatan reproduksi yang umum terjadi dengan prevalensi yang tinggi terutama di kalangan dewasa muda. Namun, tanda dan gejala gangguan menstruasi sering diabaikan. Tujuan penelitian ini adalah untuk mengetahui prevalensi masalah menstruasi dan perilaku mencari pengobatan. Penelitian deskriptif crosssectional dilakukan pada 261 mahasiswi. Data dikumpulkan menggunakan kuesioner terstruktur. Prevalensi gejala pramenstruasi sebesar $70,1 \%$, dan prevalensi dismenore sebesar 93,6\%. Informasi tentang kesehatan reproduksi sebagian besar berasal dari ibu $(65 \%)$. Perubahan suasana hati/iritabilitas $(88,1 \%)$ dan dismenorea $(93,5 \%)$ adalah gejala pramenstruasi dan sindrom menstruasi yang paling umum. Lebih dari separuh peserta mengalami dismenore yang parah $(53,2 \%)$, namun perilaku pencarian medis selama periode menstruasi sangat rendah (18,8\%). Peserta tidak mencari pengobatan karena menganggap masalah menstruasi tidak mengganggu kegiatan sehari-hari $(80,2 \%)$ dan enggan untuk minum obat $(8 \%)$. Kesimpulannya adalah bahwa profesi kesehatan sebaiknya melibatkan para ibu dalam diskusi umum tentang masalah menstruasi karena ibu adalah sumber utama informasi terkait kesehatan reproduksi.
\end{abstract}

\section{Kata Kunci}

Masalah menstruasi, kesehatan reproducksi, perilaku mencari pengobatan 


\section{INTRODUCTION}

Menstruation is a natural process that occurs throughout a woman's reproductive life which may be associated with various constitutional disorders [1]. There are various types of menstrual disorders, including dysmenorrhea, premenstrual symptoms, menorrhagia, polymenorrhea, abnormal vaginal bleeding, amenorrhea, and irregular menstruation [1]. Several studies have shown that a large proportion of the female population of reproductive age suffers from menstruationrelated health issues $[2,3]$, whereas $39.7 \%$ of women aged 20-29 have vaginal discharge and pruritus vulvae . In Indonesia, the proportions of women with menstrual problems were ranged from $85.9 \%$ in Medan to $91.7 \%$ in Surakarta $[4,5]$.

Menstrual problems are one of the most common causes of absenteeism and poor academic performance among young females [6]. The problems can lead to more serious health conditions, such as cardiovascular disease and bleeding $[7,8]$. Furthermore, over a third of women $(38 \%)$ with menorrhagia, a condition with heavy menstrual bleeding, were referred for surgical intervention [9]. A previous study showed that $37.2 \%$ of women underwent a hysterectomy within 1-year of a referral for menorrhagia [10].

Many factors can affect menstrual patterns, including age of menarche, smoking, and physical activity [1 1]. There is also a growing evidence of an association between stress and menstrual problems in women [12]. Although conditions related to menstrual problems are not life threatening, they can seriously decrease the quality of life of many women and affect their mental health and their productivity [2]. The number of female's seeking treatment for premenstrual symptoms is on the increase globally; however, this is not the case in Indonesian context where only a few of female find treatment to overcome their menstrual problems (28\%) [13]. Moreover, little is known about treatment seeking behaviors of female with menstrual problems. In this study, we assessed the magnitude of menstrual problems and treatment seeking behaviors among college students of Universitas Islam Negeri (UIN) Syarif Hidayatullah Jakarta, Indonesia.

\section{METHOD}

\section{Study design}

This was a cross-sectional study conducted from September to Oktober 2014 in Syarif Hidayatullah State Islamic University (UIN) Jakarta, a public university in Indonesia located in Ciputat, South Tangerang, Banten.

\section{Samples of the Study}

A total of 300 female students ( $1^{\text {st }}$ to $3^{\text {rd }}$ year of college) were chosen using systematic random sampling. However, 39 students were not able to reach during the study, resulting in a total of 261 participants included in the study (response rate $=87 \%$ ). Written consent was obtained, and all the participants were assured that their identity would be kept confidential. A short, 15minutes briefing was carried out to explain to participants the terminologies used in the questionnaires.

\section{Data collection}

Each participant was given a questionnaire to complete. The information collected included items relating to the participants' demographic background, and menstrual pattern (menarche age and cycle length in days), characteristics of blood loss, and history of dysmenorrhea, amenorrhea, and premenstrual symptoms, and treatment seeking behavior. The participants' demographic background included age, mother's education, residence, knowledge about female's reproductive health, sources of information related to female's reproductive health, physical activity, smoking behavior and stress. The reliability 
and validity of the questionnaire was checked using the test-retest technique. The same questionnaire was completed by 20 students, with a gap of 3 weeks in between, to determine whether they answered in the same way. The reliability of the questionnaire was 0.807 .

Frequency of premenstrual symptoms and menstrual symptoms were classified as usually ( $4-6$ times), sometimes ( $1-3$ times) and never during the last 6 months. The vaginal discharge' frequency and vulvar pruritus were classified as usually (weekly / almost daily), sometimes (2-4 weeks) and never during the last 6 months. The severity of menstrual problems was categorized into 3 levels: 1) severe if symptoms occurred and unable to perform daily activities), 2) moderate if no symptoms and disturbing, but still able to perform daily activities, 3 ) and mild if symptoms occurred, but do not interfere with daily activities. Information about stress and physical activity was collected using a series of questions adopted from previous studies. Stress was measured using Depression, Anxiety, and Stress Scale Questionnaire (DASS); physical activity was collected using the WHO Global Physical Activity Questionnaire. The total scores of 10 questions were calculated to define the level of knowledge; 1 ) low ( $\leq 5$ right answer), 2 ) adequate (6-7 correct answer), 3 ) high ( $\geq 8$ correct answer).

\section{Statistical analysis}

EpiData program was used for data entry and documentation of data. After data cleaning using EpiData program, we then exported the data into Microsoft Excel to perform data analysis. Participant characteristics were detailed using descriptive statistics, as were the prevalence of menstrual symptoms and treatment seeking behavior.

\section{RESULTS AND DISCUSSION}

Majority of the participant's age was less than 21 years old (95\%). Participants' knowledge about reproductive health were more likely to be in average, and the source of information was mostly from their mothers $165 \%$ ) although only $45 \%$ participants lived with their mothers and less than one third of mothers had diploma from primary schools. Participants were more likely to have normal cycle length of menstruation $(73 \%)$, and had age of menarche $\geq 12$ years (86\%) (Table $1)$.

Table 1. Participants' characteristics, $n=261$

\begin{tabular}{|c|c|c|}
\hline Characteristics & ${ }^{*} \mathrm{n}$ & $\%$ \\
\hline \multicolumn{3}{|l|}{ Age, years } \\
\hline$<21$ & 248 & 95,0 \\
\hline$\geq 21$ & 13 & 5,0 \\
\hline \multicolumn{3}{|l|}{ Residence } \\
\hline Live in dormitory/rented room & 131 & 50,2 \\
\hline Live with relatives & 13 & 5,0 \\
\hline Live with parents & 117 & 44,8 \\
\hline \multicolumn{3}{|l|}{ Mother's highest education } \\
\hline Elementary school & 37 & 14.2 \\
\hline Middle school & 34 & 13,0 \\
\hline High school & 102 & 39,1 \\
\hline College/university & 88 & 33,7 \\
\hline \multicolumn{3}{|l|}{$\begin{array}{l}\text { Knowledge about health } \\
\text { reproduction }\end{array}$} \\
\hline Low & 73 & 28,0 \\
\hline Average & 108 & 41,3 \\
\hline High & 80 & 30,7 \\
\hline \multicolumn{3}{|l|}{$\begin{array}{l}\text { Source of information related } \\
\text { health reproduction }\end{array}$} \\
\hline Mother & 169 & 64,8 \\
\hline Father & 7 & 2,7 \\
\hline Friends & 112 & 42,9 \\
\hline Relatives & 74 & 28,4 \\
\hline Teachers & 163 & 62,4 \\
\hline Media & 225 & 86,2 \\
\hline Health officer & 2 & 0,8 \\
\hline \multicolumn{3}{|l|}{$\begin{array}{l}\text { Duration of menstruation cycle, } \\
\text { days }\end{array}$} \\
\hline$<21$ (polymenorrhea) & 64 & 24,5 \\
\hline $21-35$ (normal) & 200 & 72,8 \\
\hline 36-90 (oligomenorrhea) & 7 & 2,7 \\
\hline \multicolumn{3}{|l|}{ Age of menarche, years } \\
\hline$<12$ & 37 & 14,2 \\
\hline$\geq 12$ & 224 & 85,8 \\
\hline
\end{tabular}

"n: number; \%: percentage

Half of the participants reported premenstrual symptoms that they sometimes had, including lower backpain, sore breast and mood swings or irritability, while $52.9 \%$ 
of participants reported never had headache. Participants reported that they had usually dysmenorrhea $(53.2 \%)$, had never less blood flow $(53.3 \%)$, and had sometimes backpain $(50.5 \%)$ and menorrhagia $(47.5 \%)$ (Table 2$)$.

Table 2. The frequency of premenstrual symptoms and menstrual syndrome among college students

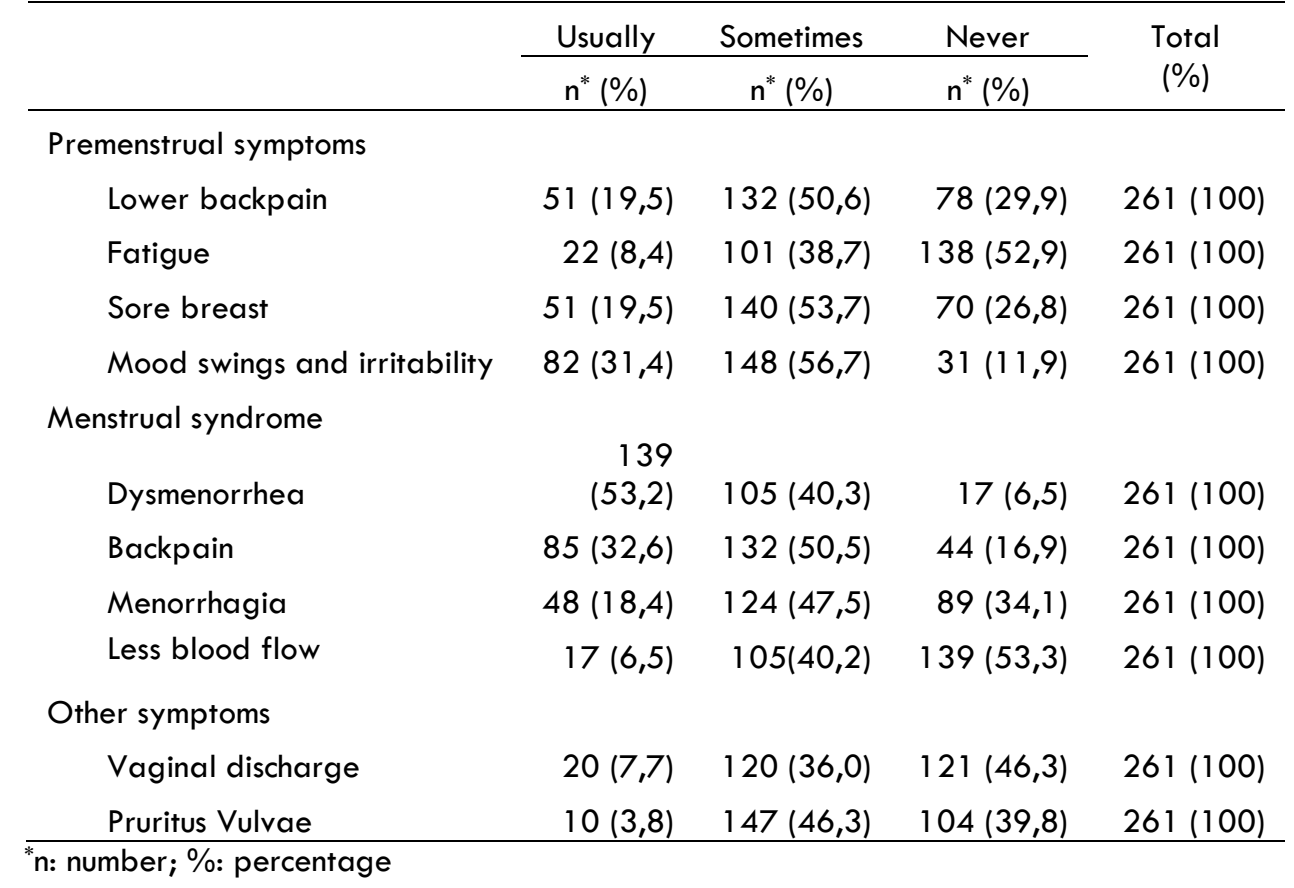

Table 3. Proportions of premenstrual symptoms and menstrual syndrome according to its severity

\begin{tabular}{|c|c|c|c|c|}
\hline & Severe & Moderate & Mild & \multirow{2}{*}{$\begin{array}{c}\text { Total } \\
(\%)\end{array}$} \\
\hline & *n $(\%)$ & ${ }^{*} \mathrm{n}(\%)$ & ${ }^{*} \mathrm{n}(\%)$ & \\
\hline \multicolumn{5}{|l|}{ Premenstrual symptoms } \\
\hline Lower backpain & $8(4,4)$ & $84(45,9)$ & $91(49,7)$ & $183(100)$ \\
\hline Fatigue & $7(5,6)$ & $39(31,5)$ & $78(62,9)$ & $124(100)$ \\
\hline Sore breast & $7(3,7)$ & $64(33,5)$ & $120(62,8)$ & $191(100)$ \\
\hline Mood swings and irritability & $14(6,1)$ & $93(40,4)$ & $123(53,5)$ & $230(100)$ \\
\hline \multicolumn{5}{|l|}{ Menstrual syndrome } \\
\hline Dysmenorrhea & $51(20,9)$ & $119(48,8)$ & $74(30,3)$ & $224(100)$ \\
\hline Backpain & $21(9,7)$ & $102(47,0)$ & $94(43,3)$ & $217(100)$ \\
\hline Menorrhagia & $8(4,6)$ & $77(44,5)$ & $88(50,9)$ & $173(100)$ \\
\hline Less blood flow & $6(4,9)$ & $30(24,4)$ & $87(70,7)$ & $123(100)$ \\
\hline \multicolumn{5}{|l|}{ Other symptoms } \\
\hline Vaginal discharge & $3(2,1)$ & $39(27,7)$ & $99(70,2)$ & $141(100)$ \\
\hline Pruritus Vulvae & $5(3,2)$ & $31(19,6)$ & $122(77,2)$ & $158(100)$ \\
\hline
\end{tabular}

The proportions of premenstrual symptoms and menstrual syndrome according to
Majority of participants had mild premenstrual symptoms and other symptoms, while few participants had severe menstrual syndrome (Table 3 ). 
Participants who had premenstrual symptoms were more likely to be physically active, never smokers, and tended to have moderate level of stress. Similar proportions were shown among participants who had menstrual syndrome (Table 4). While a few participants $(18.8 \%)$ looked for treatment for their premenstrual symptoms and menstrual syndrome, majority of participants $(81.2 \%)$ did not seek any treatments. Among those who looked for treatment, general physicians and midwifery were more likely to be their health care providers $(59.2 \%)$. Participants who did not go to health care providers were more likely to let the symptoms disappeared $(64.6 \%)$. The reasons for not seeking treatment were largely because the menstrual problems did not interfere participants' daily activities (80.2\%) (Table 5).

Table 4. Proportions of premenstrual symptoms and menstrual syndrome according to physical activity, smoking behavior, and level of stress

\begin{tabular}{ccc}
\hline & $\begin{array}{c}\text { Premenstrual } \\
\text { symptoms }\end{array}$ & $\begin{array}{c}\text { Menstrual } \\
\text { Syndrome }\end{array}$ \\
\cline { 2 - 3 } & $\mathrm{n}^{*}=245(\%)$ & $\mathrm{n}^{*}=260(\%)$ \\
\hline $\begin{array}{c}\text { Physical activity } \\
\text { Yes }\end{array}$ & $190(77.6)$ & $200(76.9)$ \\
No & $55(22.3)$ & $60(23.1)$ \\
Smoking status & & \\
Yes & $5(2.0)$ & $5(2.0)$ \\
No & $240(98.0)$ & $255(98.0)$ \\
Stress & $61(24.9)$ & $66(25.4)$ \\
Moderate & $161(65.7)$ & $170(65,4)$ \\
Mild & $23(9.4)$ & $24(9.2)$ \\
Normal & &
\end{tabular}

Menstrual problems are generally perceived as minor health concerns, thus irrelevant to the public health agenda. Data on the frequency of menstrual dysfunction and treatment seeking behavior among women in developing countries are limited.
The lack of data and the private nature of menstruation preserve the belief that menstrual problems do not warrant the attention of the public health community [6].

Table 5. Reasons for not seeking treatment, $\mathrm{n}=212$

\begin{tabular}{lc}
\hline Reasons & $\mathrm{n}^{*}(\%)$ \\
\hline Did not interfere daily activities & $170(80.2)$ \\
Did not have money & $1(0.5)$ \\
Reluctant to take medication & $17(8.0)$ \\
Busy & $4(1.9)$ \\
Health facility concern & $1(0.5)$ \\
Feel shy & $4(1.9)$ \\
Feel afraid & $15(7.1)$ \\
*: number; \%: percentage &
\end{tabular}

Premenstrual symptoms and dysmenorrhoea are common gynaecologic disorders among female adolescents [9, 14]. This study identified that more than $50 \%$ participants had premenstrual symptoms or menstrual syndrome. The severity of dysmenorrhea varied greatly. The differences in severity's level reported may be explained by the effect of culture on perception in pain sensitivity [14]. Focusing on the characteristics of the menstrual cycle, majority of participants $(73 \%)$ had a normal length of menstrual cycle. However, variations in menstrual cycle duration have been shown in different populations, and intra- and inter-individual variations are also common. For instance, it has been reported that $2.2 \%$ of women in India experience shorter $(<21$ days) and $4.1 \%$ longer menstrual cycles (>35 days) [15]. In this study, $25 \%$ of the participants reported short and 3\% reported long menstrual periods.

Some studies have shown the associations of physical activity with premenstrual symptoms or menstrual syndrome [16, 17], although such associations were not observed in other studies $[6,18]$. In this study, participants who had premenstrual symptoms or menstrual syndromes were more likely to be physically active, indicating that physical activity was not related with participants' menstrual problems. Smoking can cause menstrual 
disorders because the nicotine contained in cigarettes can cause constriction of the blood vessels, resulting in the flow of endometrial blood vessels to decline [19]. Results of a previous study showed that adolescence and young adults who smoked had $25 \%$ greater risk of premenstrual syndromes [20]. However, the effect of smoking on menstrual syndromes could not be seen in this study since participants were mostly nonsmokers (98\%). Interestingly, this study observed that participants who exposed to stress were more likely to have premenstrual symptoms or menstrual syndrome. For example, out of 245 participants with premenstrual symptoms, $90.61 \%$ of them experienced stress, mild or moderate. Previous study at a university in America also showed that college students with premenstrual symptoms had greater proportions of stress $(66.6 \%)$ [21]. Menstrual disorders may occur due to the deregulations of the body's response to stressful conditions. Under stress conditions, the hypothalamic-pituitary adrenal axis (hypothalamus) plays a gonadotropinreleasing hormone in the pulse. Therefore, stress can cause irregularities in the menstrual cycle and ovulatory disruption [22].

Treatment of menstrual syndrome should be directed at providing relief from the cramping pelvic pain and associated symptoms. Non-steroidal anti-inflammatory drugs and oral contraceptives are reported as providing the most effective treatment [6]. The use of oral contraceptives by unmarried female is, however, culturally unacceptable in our traditional and conservative community. In this study, only $18 \%$ of the students consulted health care provider. This is consistent with other findings that most adolescents with menstrual syndromes selfmedicate with the over-the counter preparations [6, 23]. Majority of the participants in this study did not seek for health care provider because they felt menstrual problems did not interfere with their daily activities $(80 \%)$ and they felt reluctant to take medication $(8 \%)$.
This study used the validated questionnaire to explore menstrual problems and treatment seeking behavior among college students. However, there are several limitations of the present study; for instance, it was a cross sectional study, so it was not possible to conclude a causative relationship between psychological stress and menstrual problems. The effect of other confounding factors, such as body mass index, use of oral contraceptive pills, lack of sleep, and parents' socioeconomic status were not considered. Moreover, the analysis relied on data obtained using questionnaire, and no history was taken, or medical examination/investigations performed.

\section{CONCLUSION}

In this study, premenstrual symptoms and menstrual syndrome are highly prevalent among college students of UIN Jakarta, with highly variable in its severity. Mothers were the main source of information about reproductive health, and the most common of premenstrual symptoms reported were lower backpain, mood swings and irritability, sore breast and fatigue. Those who exposed to stress were more likely to have premenstrual symptoms or menstrual syndrome. Majority of the participants did not seek for health care provider because they felt that menstrual problems did not interfere their daily activities.

\section{ACKNOWLEDGMENT}

We thank the Universitas Islam Negeri (UIN) Syarif Hidayatullah Jakarta for collaboration and cordial support. We also thank the students majoring Epidemiology of the Study Program of Public Health Faculty of Health Sciences UIN for their role in data collecting. We are grateful to the study subjects for their participation in this survey. 


\section{REFERENCE}

1. Jarrell, J.: 'The significance and evolution of menstruation', Best practice \& research. Clinical obstetrics \& gynaecology, 2018, 50, pp. 18-26

2. Chia, C.F., Lai, J.H., Cheung, P.K., Kwong, L.T., Lau, F.P., Leung, K.H., Leung, M.T., Wong, F.C., and Ngu, S.F.: 'Dysmenorrhoea among Hong Kong university students: prevalence, impact, and management', Hong Kong medical journal $=$ Xianggang yi xue za zhi, 2013,19 , (3), pp. 222-228

3. Karout, N., Hawai, S.M., and Altuwaijri, S.: 'Prevalence and pattern of menstrual disorders among Lebanese nursing students', East Mediterr Health J, 2012, $18,(4)$, pp. 346-352

4. Amini, R., Raden, A., Hidayati, R.S., Dewi, Y.L.R., and Indrayanto, Y.: 'The effect of passive smoking on the incidence of primary dysmenorrhea', Folia Medica Indonesiana, 2011, 47, (3), pp. 160-165

5. Purba, F.S., Sarumpaet, S.M., and Jemadi: 'Faktor - Faktor yang Berhubungan Dengan Disminor pada Siswi SMK Negeri 10 Medan Tahun 2013', Gizi, Kesehatan Reproduksi dan Epidemiologi, 2013, 2, (5)

6. Lakshmi, A.S., Saraswathi, I., Saravanan, A., and Ramamchandran, C.: 'Prevalence of premenstrual syndrome and dysmenorrhoea among female medical students and its association with college absenteeism', International Journal of Biological and Medical Research, 2011, 2, (4), pp. $111-116$

7. Chi, C., Pollard, D., Tuddenham, E.G., and Kadir, R.A.: "Menorrhagia in adolescents with inherited bleeding disorders', Journal of pediatric and adolescent gynecology, 2010, 23, (4), pp. $215-222$

8. Solomon, C.G., Hu, F.B., Dunaif, A., RichEdwards, J.E., Stampfer, M.J., Willett, W.C., Speizer, F.E., and Manson, J.E.: 'Menstrual cycle irregularity and risk for future cardiovascular disease', The Journal of clinical endocrinology and metabolism, 2002, 87, (5), pp. 20132017

9. Grant, C., Gallier, L., Fahey, T., Pearson, N., and Sarangi, J.: 'Management of menorrhagia in primary care-impact on referral and hysterectomy: data from the Somerset Morbidity Project', Journal of epidemiology and community health, 2000, 54, (9), pp. 709-713

10. Geary, R.S., Gurol-Urganci, I., Kiran, A., Cromwell, D.A., Bansi-Matharu, L., Shakespeare, J., Mahmood, T., and van der Meulen, J.: 'Factors associated with receiving surgical treatment for menorrhagia in England and Wales: findings from a cohort study of the National Heavy Menstrual Bleeding Audit', BMJ open, 2019, 9, (2), pp. e024260

11. Liv, Y., Gold, E.B., Lasley, B.L., and Johnson, W.O.: 'Factors affecting menstrual cycle characteristics', American journal of epidemiology, 2004, 160, (2), pp. 131-140

12. Yamamoto, K., Okazaki, A., Sakamoto, Y., and Funatsu, M.: 'The relationship between premenstrual symptoms, menstrual pain, irregular menstrual cycles, and psychosocial stress among Japanese college students', Journal of physiological anthropology, 2009, 28, (3), pp. 129-136

13. Lestari, H., Metusala, J., and Suryanto, D.Y.: 'Gambaran Dismenorea pada 
Remaja Putri Sekolah Menengah Pertama di Manado', Sari Pediatri, 2010, 12, (2), pp. 99-102

14. Banikarim, C., Chacko, M.R., and Kelder, S.H.: 'Prevalence and impact of dysmenorrhea on Hispanic female adolescents', Archives of pediatrics \& adolescent medicine, 2000, 154, (12), pp. 1226-1229

15. Omidvar, S., and Begum, K.: "Menstrual pattern among unmarried women from south India', Journal of natural science, biology, and medicine, 2011, 2, (2), pp. 174-179

16. Samadi, Z., Taghian, F., and Valiani, M.: 'The effects of 8 weeks of regular aerobic exercise on the symptoms of premenstrual syndrome in non-athlete girls', Iranian journal of nursing and midwifery research, 2013, 18, (1), pp. 14-19

17. Seedhom, A.E., Mohammed, E.S., and Mohammed, E.M.: 'Lifestyle Factors Associated with Premenstual Syndrome among El-Minia University Students, Egypt', ISRN Public Health, 2013, 2013

18. Fekr, L.Z., Zadeh, T.A.M., J. B., and Salehian, M.H.: 'Comparison of disorders menstrual frequency between female athlete and nonathlete university students', European Journal of Experimental Biology, 2012,2 , (4), pp. 944-947
19. Chen, C., Cho, S.l., Damokosh, A.l., Chen, D., Li, G., Wang, X., and Xu, X.: 'Prospective study of exposure to environmental tobacco smoke and dysmenorrhea', Environmental health perspectives, 2000, 108, (11), pp. 1019-1022

20. Bertone-Johnson, E.R., Hankinson, S.E., Johnson, S.R., and Manson, J.E.: 'Cigarette smoking and the development of premenstrual syndrome', American journal of epidemiology, 2008, 168, (8), pp. 938-945

21. Tabassum, S., Afridi, B., Aman, Z., Tabassum, W., and Durrani, R.: 'Premenstrual syndrome: frequency and severity in young college girls', JPMA. The Journal of the Pakistan Medical Association, 2005, 55, (12), pp. 546-549

22. Allsworth, J.E., Clarke, J., Peipert, J.F., Hebert, M.R., Cooper, A., and Boardman, L.A.: 'The influence of stress on the menstrual cycle among newly incarcerated women', Women's health issues : official publication of the Jacobs Institute of Women's Health, 2007, 17, (4), pp. 202-209

23. Davis, A.R., and Westhoff, C.L.: 'Primary dysmenorrhea in adolescent girls and treatment with oral contraceptives', Journal of pediatric and adolescent gynecology, 2001, 14, (1), pp. 3-8 